\title{
MEALS FOR TWO: FORAGING ACTIVITY OF THE BUTTERFLYFISH Chaetodon striatus (PERCIFORMES) IN SOUTHEAST BRAZIL
}

\author{
BONALDO, R. M., KRAJEWSKI, J. P. and SAZIMA, I. \\ Departamento de Zoologia e Museu de História Natural, C.P. 6109, \\ Universidade Estadual de Campinas, CEP 13083-970, Campinas, São Paulo, Brazil \\ Correspondence to: Roberta Martini Bonaldo, Departamento de Zoologia and Museu de História Natural, \\ C.P. 6109, Universidade Estadual de Campinas, CEP 13083-970, Campinas, São Paulo, Brazil, \\ e-mail: robertabonaldo@yahoo.com \\ Received October 1, 2003 - Accepted October 21, 2003 - Distributed May 31, 2005
}

(With 2 figures)

\begin{abstract}
The banded butterflyfish (Chaetodon striatus) from the tropical and subtropical western Atlantic is a territorial, diurnal forager on benthic invertebrates. It is usually seen moving singly or in pairs, a few meters above the sea floor. We studied the foraging activity of $C$. striatus on rocky reefs in southeastern Brazil. This fish spent about $11 \mathrm{~h}$ and 30 min per day on feeding activities, and preferred colonies of non-scleratinian anthozoans over sandy and rocky substrata while foraging. The lowest feeding rates were recorded in the early morning and late afternoon, but we found no further differences between feeding rates throughout the day. We also found no differences between the feeding rates of paired and single individuals.
\end{abstract}

Key words: Chaetodontidae, foraging, substrate preferences, southwestern Atlantic.

\section{RESUMO}

\section{Refeição para dois: atividade de forrageamento do peixe-borboleta Chaetodon striatus (Perciformes) no sudeste do Brasil}

O peixe-borboleta (Chaetodon striatus) do Atlântico ocidental tropical e subtropical é uma espécie territorial, diurna e que forrageia sobre invertebrados bentônicos, sendo geralmente encontrada aos pares ou solitária, nadando poucos metros acima do substrato. Estudamos a atividade de forrageamento dessa espécie em recifes rochosos no sudeste brasileiro. O peixe-borboleta despende cerca de $11 \mathrm{~h}$ e 30 min em atividades alimentares por dia e prefere colônias de antozoários a substratos arenosos e rochosos para o forrageamento. As menores taxas de forrageamento foram registradas ao amanhecer e ao entardecer, não sendo encontradas outras diferenças nessa freqüência ao longo do dia. Não foram encontradas diferenças entre a freqüência alimentar de indivíduos aos pares e solitários.

Palavras-chave: Chaetodontidae, forrageamento, seleção de substrato, Atlântico Sul Ocidental.

\section{INTRODUCTION}

The butterflyfishes (Chaetodontidae) are conspicuous components of the reef community on tropical and subtropical coral reefs (Pitts, 1991). These fishes swim by daylight, often in pairs, and reside for up to five years in the same reef area and with the same partner (Reese, 1973; Fricke, 1986; Driscoll \& Driscoll, 1988). Consequently, mates, food, and shelter are potentially defensible (Driscoll \& Driscoll, 1988; Neudecker \& Lobel, 1982). Swimming in pairs and mutual partner guarding are regarded as a joint territorial advertisement that minimizes agonistic interactions between territory holders (Fricke, 1986). 
Chaetodontidae are mostly bottom-foragers, although some species forage for plankton in the water column (Hobson, 1974, 1991; Motta, 1988). The diet of the bottom-foraging species is composed mostly by anthozoans, polychaetes, small crustaceans, and mollusk eggs (Hiatt \& Strasburg, 1960; Randall, 1967; Sano, 1989). Most of the knowledge about feeding activity of butterflyfishes originates from studies in the Caribbean (e.g., Birkeland \& Neudecker, 1981; Pitts, 1991) and the Pacific (e.g., Hobson, 1974; Irons, 1989; Tricas, 1989).

The banded butterflyfish, Chaetodon striatus, is found throughout the Western Atlantic, from New Jersey in the U.S.A. to Santa Catarina in Brazil (Carvalho-Filho, 1999). It is often found in pairs on shallow coral and rocky reefs (Menezes \& Figueiredo, 1985). This fish is mostly a bottomforager (Pitts, 1991), although it may forage for plankton in the water column (Sazima \& Sazima, 2001). Its diet is composed primarily by nonscleratinian anthozoans and polychaetes (Randall, 1967; Motta, 1989; Pitts, 1991).

We studied the foraging of $C$. striatus in the SW Atlantic, a region where information about the ecology of this butterflyfish is scarce (Menezes \& Figueiredo, 1985; Carvalho-Filho, 1999), especially that related to feeding (Sazima \& Sazima, 2001). Our study addressed the three following questions about the foraging activity of $C$. striatus: is there any substrate selection for foraging? Do the feeding rates differ throughout the day? Do the feeding rates of paired and single individuals differ?

\section{MATERIAL AND METHODS}

\section{Study site}

The field study was conducted on the Ilha de São Sebastião (2346' S, 45 $21^{\prime}$ 'W), off the coast of São Paulo in southeastern Brazil, from February to June 2002. The study site was located on rocky reefs covered mostly by algae; by zoanthid colonies, mostly Palythoa caribaeorum, and P. variabilis; and by the hard coral Mussismilia hispida. It also covered adjacent sandy areas. During our study, horizontal visibility was 2-7 $\mathrm{m}$, and water temperature was $26-27^{\circ} \mathrm{C}$. Depth at the study site ranged from 1 to $3 \mathrm{~m}$.

\section{Procedure}

The foraging activity of $C$. striatus was observed in eight nonconsecutive days, while snorkelling. During observational sessions of 60$150 \mathrm{~min}$, "focal animal" and "all occurrences" samplings (Lehner, 1979) were used in $371 \mathrm{~min}$ of direct observation. The foraging activity of $C$. striatus was assessed by following individuals for 1-5 min and counting the number of bites on the three available substrate types (anthozoan colonies, and rocky as well as sandy bottoms). To avoid the risk of biased samples, individuals were not followed over successive periods (Birkeland \& Neudecker, 1981).

The observations were conducted at daytime, from sunrise $(5: 30 \mathrm{~h})$ to sunset $(18: 45 \mathrm{~h})$. No nocturnal observations were conducted, as $C$. striatus is inactive at night (Starck \& Davis, 1966, pers. obs.). The distance between the pair members changed during their foraging, making impracticable the observation of both individuals at the same time. Thus, only one of the partners was followed during the observational sessions. We considered as single an individual whose partner was not visible throughout a 1-5 min session. In a total of 100 foraging bouts, 58 occurred in the morning (5:00 h13:00 h) and 42 in the afternoon (13:01 h-19:00 h). Additionally, of these 100 bouts, 62 focused on paired individuals and 38, on single ones.

We assessed the availability of the three foraging substrate types (anthozoan colonies, and rocky and sandy bottoms) with six $10 \times 2 \mathrm{~m}$ transects (modified from Birkeland \& Neudecker, 1981). The transects started on the rocky shore and ended in the sandy area where $C$. striatus was still observed feeding.

Kruskal-Wallis one-way analysis of variance was used to compare the number of bites per min for successive periods of $120 \mathrm{~min}$ of foraging time throughout the day. As the Kruskal-Wallis was significant, a posteriori tests were made to compare pairs of 120 min periods, for identifying which period(s) caused the differences. The goodness-offit test was used to determine the substrate selection by $C$. striatus. Two-way ANOVA was used to test for differences in feeding rates between paired and single individuals, and between morning and afternoon. The time spent during feeding bouts was 
compared between paired and single individuals by means of the Student's t test (Zar, 1999).

\section{RESULTS}

The feeding activity of $C$. striatus started about $30 \mathrm{~min}$ after sunrise $(5: 45 \mathrm{~h})$ and ended shortly before nightfall (18:26 h), totaling about $11 \mathrm{~h}$ and $30 \mathrm{~min}$ of feeding activity per day. The feeding rate of $C$. striatus was $1.60+1.76$ bites min $^{-1}$ (average + standard error, $\mathrm{n}=100)$. The fish foraged predominantly on anthozoans over sandy and rocky bottoms $\left(\mathrm{X}_{2}^{2}=26.44, \mathrm{p}<0.001\right.$; Fig. 1), and selected only the non-scleratinians (zoanthids) Palythoa variabilis and $P$. caribaeorum.

Feeding frequency varied throughout the day $\left(\mathrm{H}_{6}=19.92\right.$, $\mathrm{p}=0.003$; Fig. 2). The lowest feeding rates were recorded in the early morning and late afternoon (in some observational sessions C. striatus did not forage at all). We found no significant differences between the morning and afternoon feeding rates nor between paired and single individuals $\mathrm{F}_{1}=$ $0.24, \mathrm{p}=0.63$ (Table 1). On the other hand, the foraging bouts of paired individuals $(x=247+$ $\mathrm{SD}=72 \mathrm{~s})$ were longer than those of the single ones $(x=195 \mathrm{~s}+\mathrm{SD}=92 \mathrm{~s})\left(\mathrm{t}_{96}=3.14, \mathrm{p}<0.005\right)$.

\section{DISCUSSION}

We found that the time $C$. striatus spends foraging is high when compared to the values obtained for $C$. trifascialis from the Johnston Atoll $\left(16^{\circ} 45^{\prime} \mathrm{N}, 169^{\circ} 31^{\prime} \mathrm{W}\right)$ in the Pacific, the only other study in which data were collected from sunrise to sunset (Irons, 1989). For C. trifascialis, a total of $10 \mathrm{~h}$ per day were spent feeding (Irons, 1989), a value slightly below that obtained in our study (11 $\mathrm{h}$ and $30 \mathrm{~min}$ ). The slightly higher foraging activity here recorded for $C$. striatus may be related to the higher latitude and greater number of daylight hours (our study took place in austral summer). Since $C$. trifascialis and $C$. striatus are diurnally active (Starck \& Davis, 1996; Irons, 1989), it was to be expected that $C$. striatus in São Sebastião island would forage for a larger period than did C. trifascialis in Hawaii.

Our estimates of the feeding rates of $C$. striatus are low when compared to the values found for $C$. capistratus $\left(5.88+1.96\right.$ bites $\left.\mathrm{min}^{-1}\right)$ in the Caribbean (Birkeland \& Neudecker, 1981) and $C$. trifascialis $\left(8.45+0.72\right.$ bites $\left.\mathrm{min}^{-1}\right)$ in the Pacific, both of which feed almost exclusively on hard corals (Randall, 1967; Birkeland \& Neudecker, 1981; Motta, 1989). However, the feeding rates of $C$. striatus are similar to those recorded for the butterflyfish Prognathodes aculeatus in the Caribbean $\left(2.44+0.92\right.$ bites $\left.\mathrm{min}^{-1}\right)$, which feeds on invertebrates such as polychaetes and crustaceans (as C. striatus also does, see Randall, 1967; Birkeland \& Neudecker, 1981; Motta, 1989). Butterflyfish species that feed on hard coral exhibit significantly more bites than species feeding on polychaetes and crustaceans (Birkeland \& Neudecker, 1981). Thus, the differences recorded for the feeding rates of $C$. capistratus and $C$. trifascialis versus $P$. aculeatus and $C$. striatus are due to diet, as invertebrates have a higher caloric value than do hard corals (Birkeland \& Neudecker, 1981; Motta, 1989).

In our study $C$. striatus selected nonscleratinian anthozoans, whose colonies shelter polychaetes and crustaceans (Gleibs et al., 1995). Therefore, it is possible, although yet to be verified, that $C$. striatus from southeast Brazil also includes these associated invertebrates in its diet, as already has been recorded for the Caribbean (Randall, 1967; Pitts, 1991).

TABLE 1

Two-way ANOVA for the number of bites per min recorded for Chaetodon striatus in two daytime periods: morning (5:00 h-13:00 h) and afternoon (13:01 h-19:00 h), and two social categories (paired and single individuals).

\begin{tabular}{|c|c|c|c|c|}
\hline Sources & df & Mean square & F & p \\
\hline Periods (morning/afternoon) & 1 & 1.768 & 0.564 & 0.45 \\
\hline Categories (paired/single) & 1 & 0.751 & 0.240 & 0.63 \\
\hline Interaction & 1 & 3.743 & 1.194 & 0.277 \\
\hline
\end{tabular}




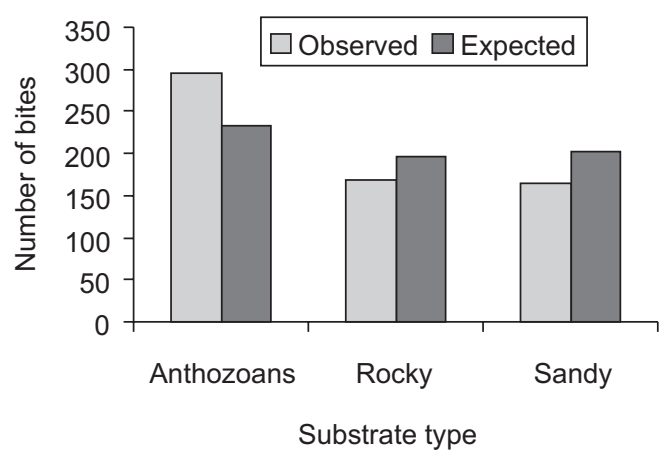

Fig. 1 - Number of expected and observed bites by Chaetodon striatus on three feeding substrate types in São Sebastião island, São Paulo, southeast Brazil.

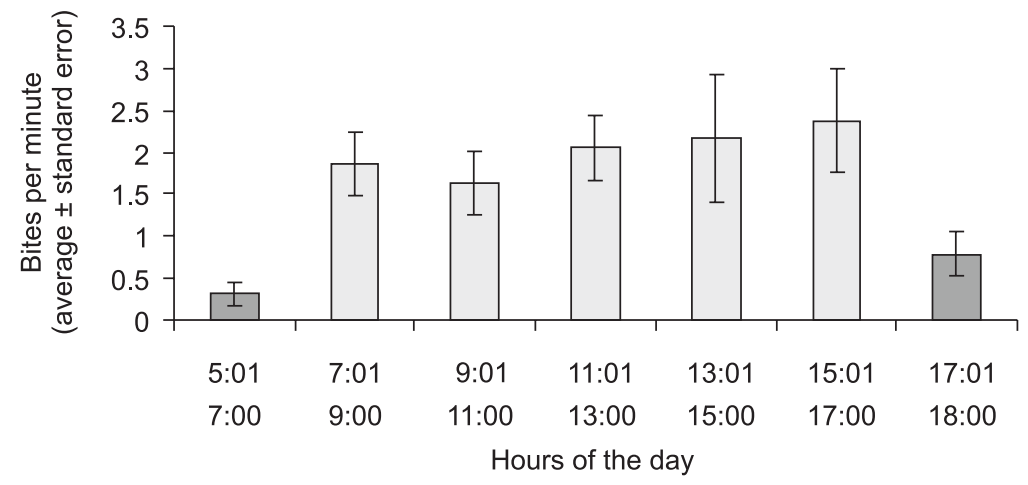

Fig. 2 - Comparison limits of bites by $C$. striatus per min. on three substrate types during the day. Bars showing the same pattern are not significantly different.

The feeding frequency variation throughout the day here recorded for C. striatus is mostly due to the beginning and the end of its feeding activity, at which times it feeds little or not at all. Also, the nonsignificant differences between morning and afternoon feeding rates are similar to what was recorded in the Caribbean for $P$. aculeatus (Birkeland \& Neudecker, 1981), whose diet is similar to that of C. striatus (Randall, 1967). On the other hand, $C$. trifascialis, which feeds on almost exclusively on Acropora hard corals that have maximal lipid production during this period (Irons, 1989), does so at a significantly higher rate in the early afternoon (Irons, 1989). Furthermore, we found no significant differences between the feeding rates of paired and single individuals of $C$. striatus, which contrasts with the findings of Fricke (1986) for Chaetodon chrysurus in the Red Sea.

Butterflyfishes defend territories in pairs and move with mutual partner guarding, a behavior regarded as a joint territorial advertisement (Fricke, 1986; Roberts \& Ormond, 1992). The removal of one member in a $C$. chrysurus pair resulted in territories being reduced to one quarter of the same area held when defended by pairs (Fricke, 1986). In addition, the distance covered per time unit by the remaining fish greatly increased, primarily because they now had to defend the area against an increased number of intruders. Thus, we probably found no differences between the feeding rates of paired and single individuals because in our study the partners stayed away from each other for short 
periods only, which were presumably insufficient to cause an increase of intruders within the butterflyfish territories. We also surmise that the removal of one of the $C$. striatus partners will result in reduction of the remaining partner's feeding rate, in a way similar to that recorded for C. chrysurus (Fricke, 1986).

Acknowledgements - We thank P. R. Guimarães-Jr. and C. A. Magalhães for help with the statistical analysis; C. Sazima and J. Zuanon for comments on the manuscript; and CNPq and FAPESP for essential financial support.

\section{REFERENCES}

BIRKELAND, C. \& NEUDECKER, S., 1981, Foraging behavior of two Caribbean chaetodontids: Chaetodon capistratus and C. aculeatus. Copeia (1): 169-178.

CARVALHO-FILHO, A., 1999, Peixes: costa brasileira. 3a ed. Editora Melro, São Paulo, 283p.

DRISCOLL, J. W. \& DRISCOLL, J. L., 1988, Pair behavior and spacing in butterflyfishes (Chaetodontidae). Env. Biol. Fish., 22(1): 29-37.

FRICKE, H. W., 1986, Pair swimming and mutual partner guarding in monogamous butterflyfish (Pisces: Chaetodontidae): a joint advertisement for territory. Ethology, 73: 307-333.

GLEIBS, S., MEBS, D. \& WERDING, B., 1995, Studies on the origin and distribution of palyotoxin in a Caribbean coral reef. Toxicon, 33: 1531-1537.

HIATT, R. W. \&. STRASBURG, D. W., 1960, Ecological relationships of the fish fauna on coral reefs of the Marshall islands. Ecol. Monogr., 30(1): 65-127.

HOBSON, E. S., 1974, Feeding relationships of teleostean fishes on coral reefs in Kona, Hawaii. Fish. Bull., 72(4): 915-1031.

HOBSON, E. S., 1991, Trophic relationships of fishes specialized to feed on zooplankters above coral reefs, pp. 69-95. In: P. F. Sale (ed.), The ecology of fishes on coral reefs. Academic Press, San Diego, 754p.

IRONS, D. K., 1989, Temporal and areal feeding behavior of the butterflyfish, Chaetodon trifascialis, at Johnston Atoll. Env. Biol. Fish., 25: 187-193.
LEHNER, P. N., 1979, Handbook of ethological methods. STPM Press, Garland, New York, 403p.

MENEZES, N. A. \& FIGUEIREDO, J. L., 1985, Manual de peixes marinhos do sudeste do Brasil. Vol. Teleostei (4), Museu de Zoologia. Universidade de São Paulo, São Paulo, 105p.

MOTTA, P. J., 1988, Functional morphology of the feeding apparatus of ten species of Pacific butterflyfishes (Perciformes, Chaetodontidae): an ecomorphological approach. Env. Biol. Fish., 22(1): 39-67.

MOTTA, P. J., 1989, Dentition patterns among Pacific and Western Atlantic butterflyfishes (Perciformes, Chaetodontidae): relationships to feeding ecology and evolutionary history. Env. Biol. Fish., 25(1-3): 159-170.

NEUDECKER, S. \& LOBEL, P. S., 1982, Mating systems of chaetodontid and pomacanthid fishes at St. Croix. Z. Tierpsychol., 59: 299-318.

PITTS, P. A., 1991, Comparative use of food and space by three Bahamian butterflyfishes. Bull. Mar. Sci., 48(3): 749-746.

RANDALL, J. E., 1967, Food habits of reef fishes of the West Indies. Stud. Trop. Oceanogr., 5: 665-847.

REESE, E. S., 1973, Duration of residence by coral reef fishes on "home" reefs. Copeia, 1973(1): 145-149.

ROBERTS, C. M. \& ORMOND, R. F. G., 1992, Butterflyfish social behaviour, with special reference to the incidence of territoriality: a review. Env. Biol. Fish., 34: 79-93.

SANO, M., 1989, Feeding habits of Japanese butterflyfishes (Chaetodontidae). Env. Biol. Fish., 25: 195-203.

SAZIMA, C. \& SAZIMA, I., 2001, Plankton-feeding aggregation and occasional cleaning by adult butterflyfish, Chaetodon striatus (Chaetodontidae), in Southwestern Atlantic. Cybium, 25: $145-151$.

STARCK, A. S. \& DAVIS, W. P., 1966, Night habits of fishes of Alligator Reef, Florida. Ichthyologica, 38: 315-356.

TRICAS, T. C., 1989, Prey selection by coral-feeding butterflyfishes: strategies to maximize the profit. Env. Biol. Fish., 25: 171-185.

ZAR, J. H., 1999, Biostatistical analysis. $4^{\text {th }}$ ed. Prentice Hall, Upper Saddle River, New Jersey, 663p. 